\title{
航空及び航海に於ける光信號の研究" IV
}

\author{
正命叫猪 狩 漺 和譯
}

\section{霧の中に於ける光の擴散}

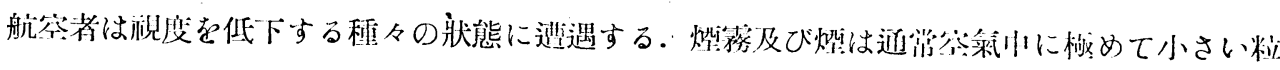

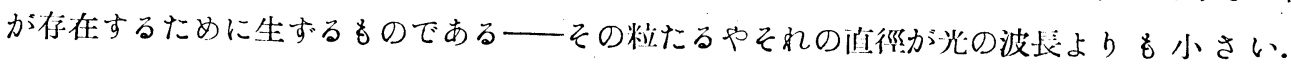

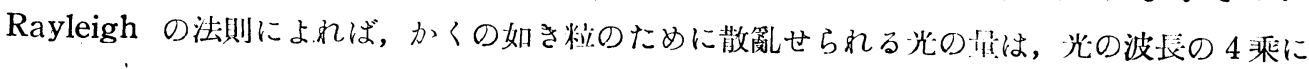

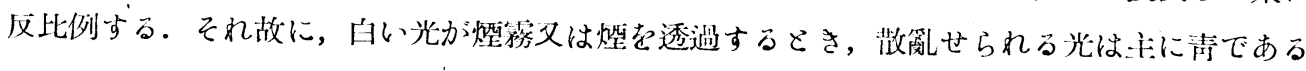
のに，これを透過した光は赫くな，突や遠い山の色が非いここ及び沒しつつある太陽の色か～ 赤いことは，この種の散微で說明することが壮承る。

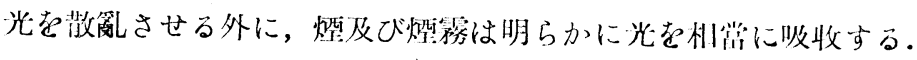

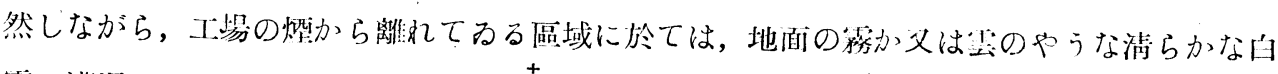

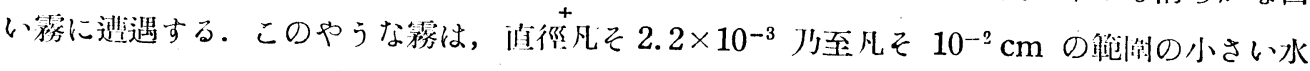

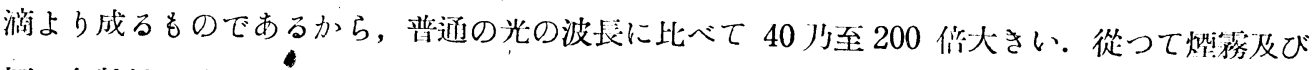

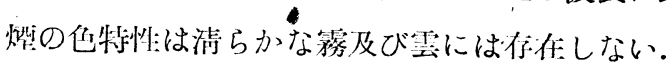

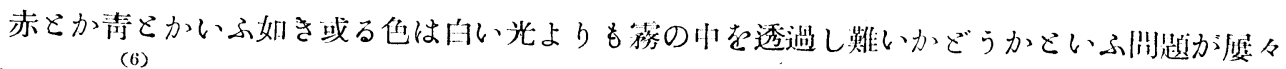

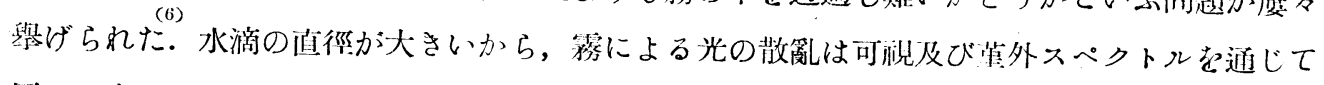

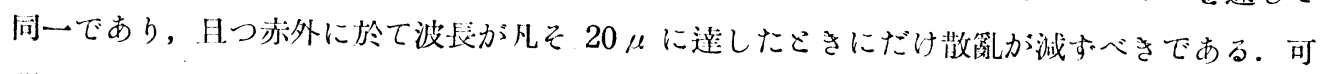

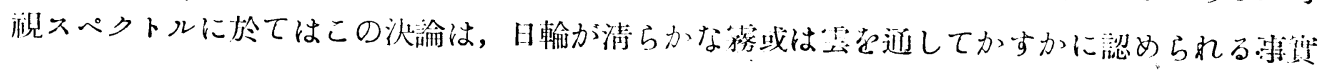
によつて確められた。文つてるる日の器明は喑れてるる日とは，はつきり違ふ色ではない事 留によつても確められた。

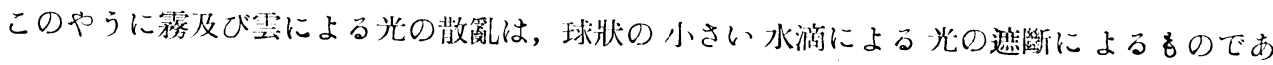

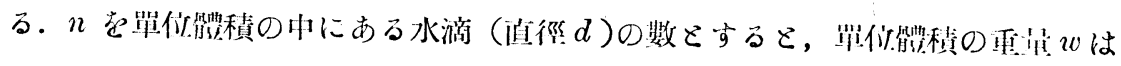

$$
w=(\pi / 6) n d^{3} \text {. }
$$

强さ $I$ の光が雲起通つて距離 $d x$ だけ通ると，直近光の出さは $-d I=I(\pi / 4) n d^{2} d x$ げ娍

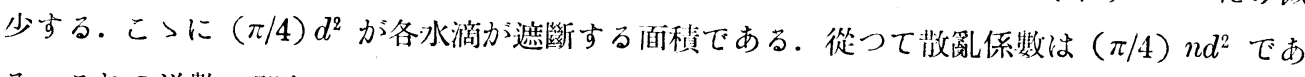
る.これの逆數, 即ち

$$
\lambda_{0}=4 /\left(\pi n d^{2}\right)=(2 / 3)(d / w)
$$

* AStudy of Light Signals in Aviation and Navigation. By I. Langmuir and W. F. Westendorp,
(Physics, 1,5 (1931-XI) 273-317)

+ Handbuch d. Exp. Physik 25 (1) p. 51 (1928).

(6) U.S. Air Services, July 1931, p. 20-25 所胾の L. H. Anderson の論文 Fog Penetration を見

よ.これは Trans. Amer. Soc. Mech. Eng.; Section on Aeronautical Engincering に践せら忆る篦. 


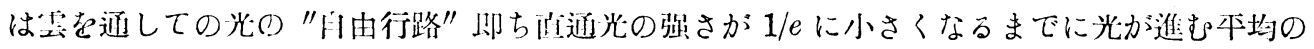

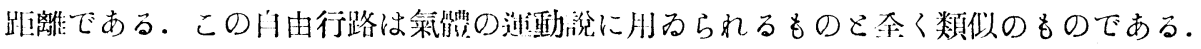

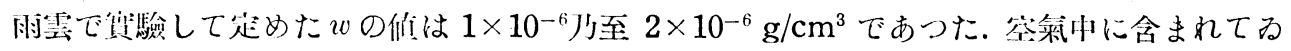
る水蒸氣の其加らwの佔の可能な最大倠を推定することが出來る。

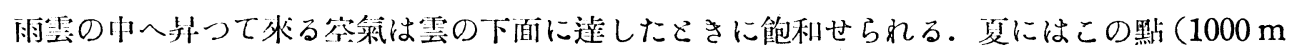
の高さ)に於ける聴度は $20^{\circ} \mathrm{C}$ を推定せられる。そのときの水蒸氣の全早は $17.2 \times 10^{-6} \mathrm{~g} / \mathrm{cm}^{3}$

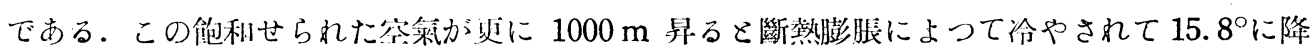

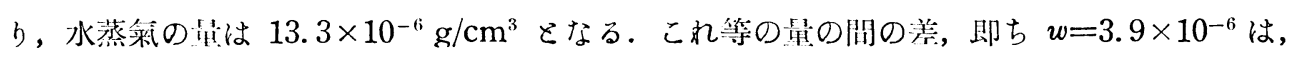
䆚さ $2000 \mathrm{~m}$ の琴の $\mathrm{cm}^{3}$ についての水滴の體積でなければならない. 雲の下面の溫度が $-5^{\circ} \mathrm{C}$ である冬の狀態に對する间梯な計算によれば， $2000 \mathrm{~m}$ の高さに於て溫度が $-11.6^{\circ}$ こなり， $w=1.4 \times 10^{-6}$ を與へる。これ等のwの优は倛驗で得られた值とよく一致する。

かくして等又は渄らかな蓩に起り得る攱も然い自由行路は大略 $w=2 \times 10^{-6}$ 及び $d=3 \times 10^{-3}$ に相常する。これ等の伿は式 (23) によつて $\lambda_{0}=1000 \mathrm{Cm}$ 蚛ち $10 \mathrm{~m}$ 克與へる. 式 (22)によ

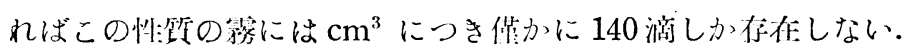

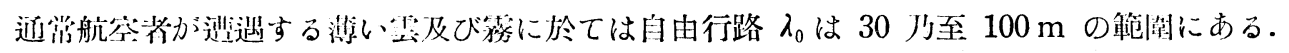

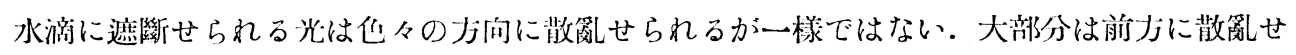

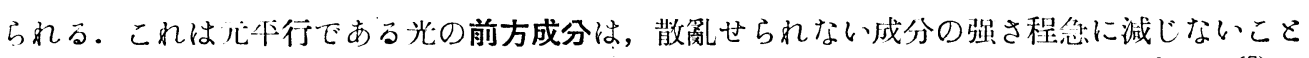

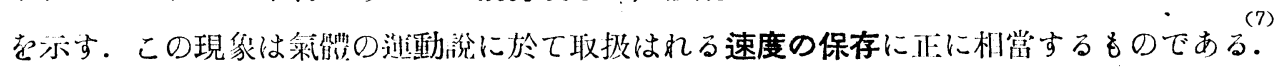

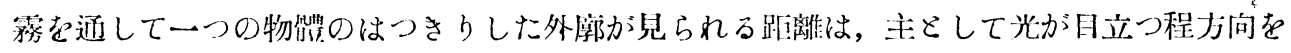

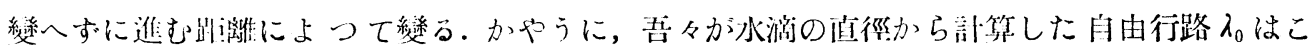
のやうな咸题に邀北し得る。

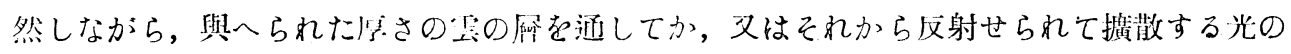

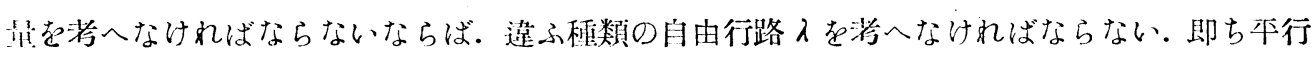

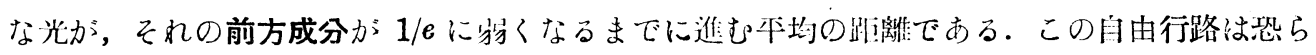
く神よりは2〜3 倍大さいだらう。

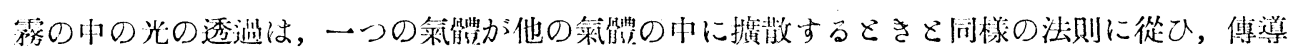
體の中の熱或は笔莱の流に類似する．揢の川の仕意の點に於ける光の强さは大略すへてのう向

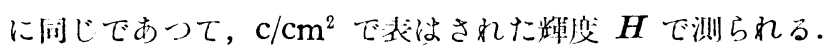

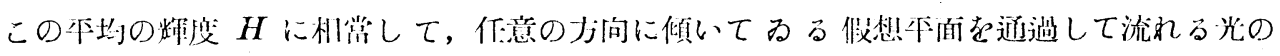

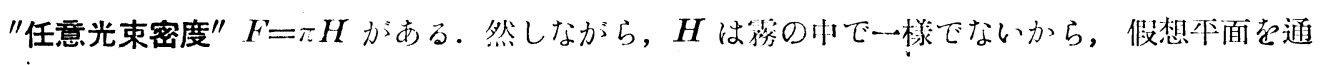

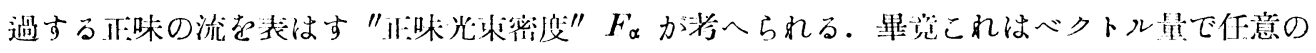
少向に於ける成分は，そのJ向に於ける，Hの㭃配に比例する。

(7) Jeans, Dynamical Theory of Gases 見上. 


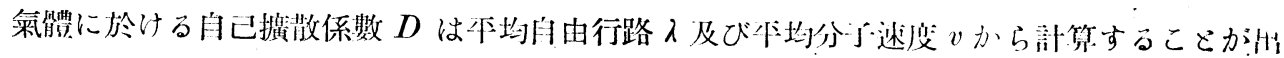

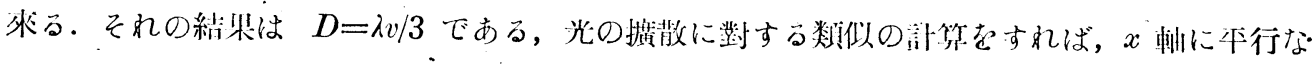
才向に於ける而味光束の成分 $F_{x}$ に對して次の式教得る。

$$
F_{x}=-(4 \pi / 3) \lambda \frac{\partial H}{\partial x} .
$$

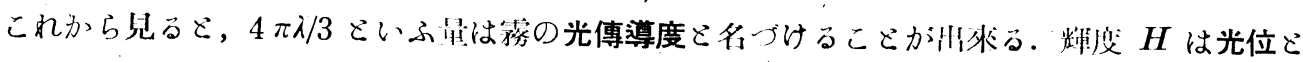

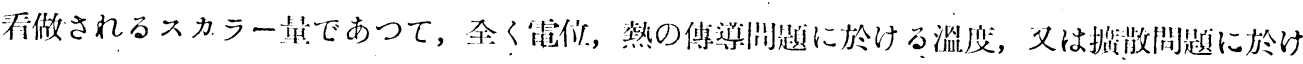
る滥度に類似守る。

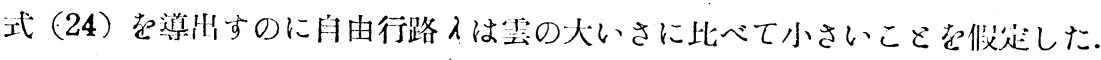

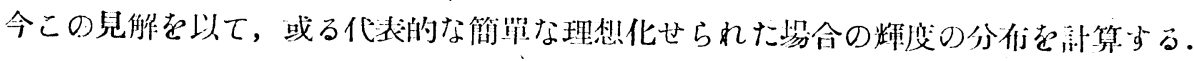

\section{1. 球形雲の中心にある點光源}

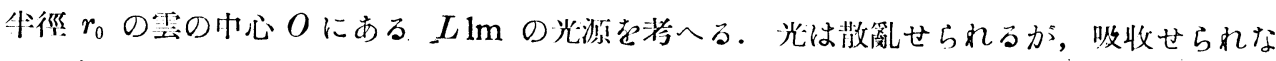
いと假定すると，中心が $O$ にある仕意の球面を近過する總光来は $L$ である。從つて川心から

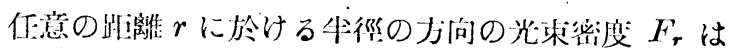

$$
F_{r}=L / 4 \pi r^{2}
$$

これを（24）と組命はせ䅡分すると

$$
H=\underset{16 \pi^{2} \lambda}{3 L}\left(\frac{1}{r}+K\right)
$$

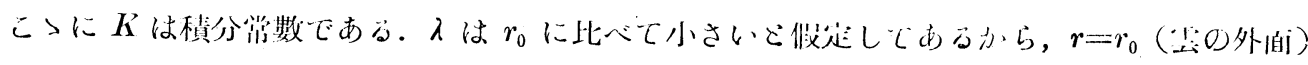
のとき $H=O$ と道くことが出來て $K=-1 / r_{0}$ 老得るから

$$
H=\frac{3 L}{16 \pi^{2} \lambda}\left(\frac{1}{r}-\frac{1}{r_{0}}\right) .
$$

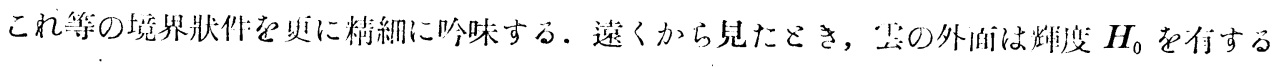

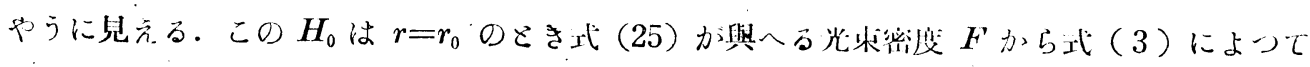
部算することか浊爽る。汃して

$$
H_{0}=L / 4 \pi^{2} r_{0}^{2} .
$$

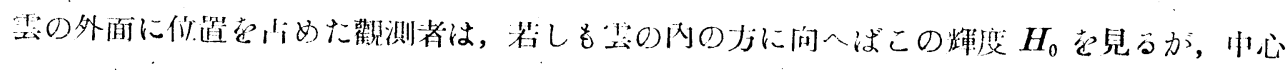

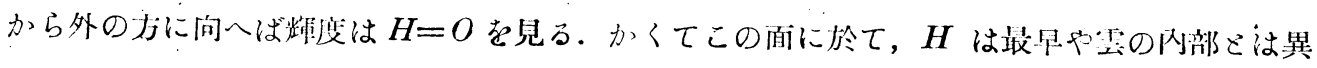

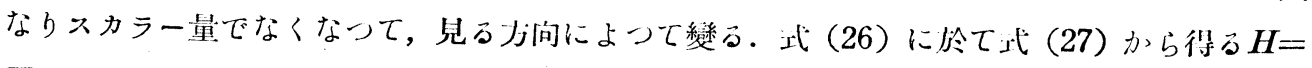
$H_{0}$ と㯰けば

$$
r_{0}-r=(4 / 3) \lambda .
$$

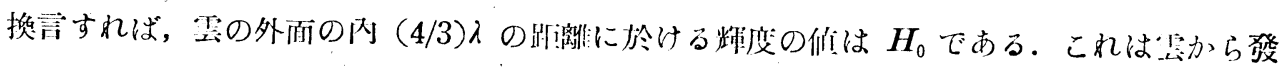

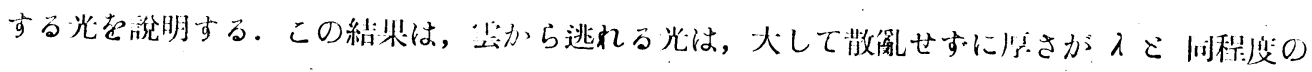




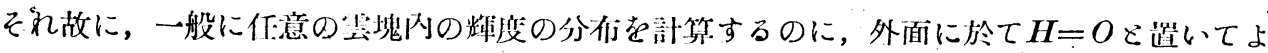

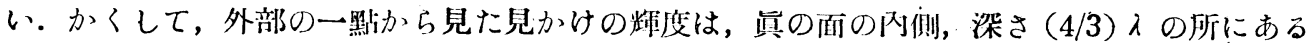
面に對して計算せられた辉度である。

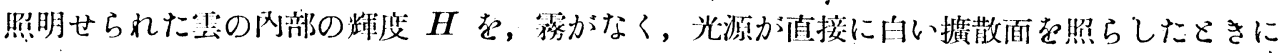

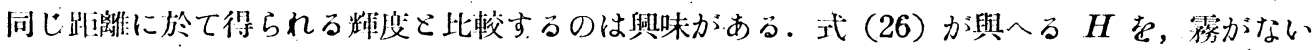

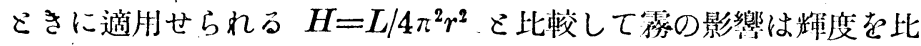

$$
3_{r}\left(r_{0}-r\right): 4 \lambda r_{0}
$$

に增すここであるこでがわかる。

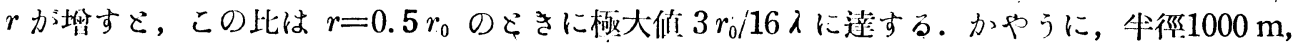
自由行路 $\lambda=30 \mathrm{~m}$ の球形の琴に於て，中心に於て $5000 \mathrm{c}$ の光 $(L=6,0000 \mathrm{~lm})$ は光源から

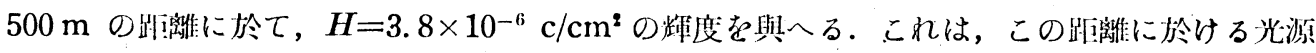
からの光が南接垂直に白い推散面を哭らしたときの輝度 $\left(0.63 \times 10^{-6}\right)$ の 6 倍以上である。か

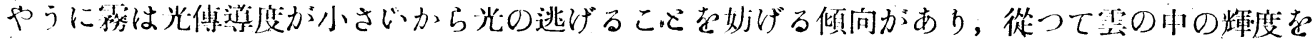
垈す。罢の外面の桄度は式に（27）によつて $H_{0}=1.5 \times 10^{-7} \mathrm{c} / \mathrm{cm}^{2}$ であつて，これは光電受 光器の限然感度の凡そ4000 估である。

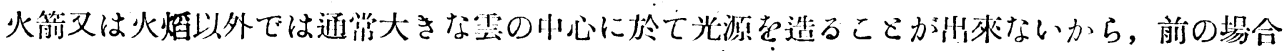
は㑕ろ學究们であるやうに見える，然しながら，例へば雪で蔽はれたこきのやうに，地面が受 ける光の殆どすべてを反射するときには，地上に厚い層の穜があり，地上に光源があるこき， 正味光束分存は式（25）が與へるもの>2 倍であり，從つて式（25）の右邀を 2 倍すると輝度 分仍が得られる。地面の反射が不完全であるごきこれ等の條件は修正せられる。

\section{霧の中の方向效果}

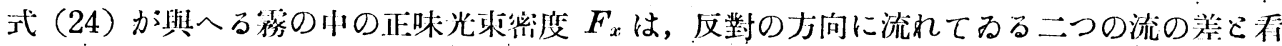

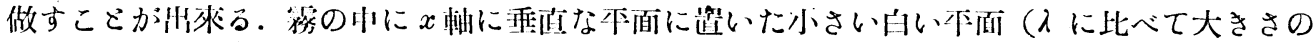
小さい）の网側は同じに照らされす，輝度の养 $\Delta H_{x}$ は

$$
\triangle H_{x}=\frac{F_{x}}{\pi}
$$

式（25）から得られる $F_{r}$ の值をこれに稙换へ，且つ式 (26) が與へる $\boldsymbol{H}$ で制るこ方向比 こして次の值を得る。

$$
{ }^{\Delta} \boldsymbol{H}_{r}=4 \lambda / 3 r\left(1-r / r_{0}\right)
$$

$r=0.5 r_{0}$ のときこの比の值は極小こなる．今考へた例に於て $\triangle H_{r} / H$ の最小优は $0.16 て ゙$

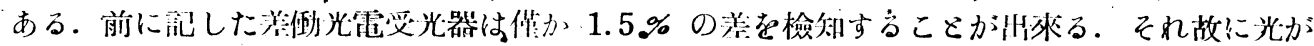


來るJ向を示すことが州來る。

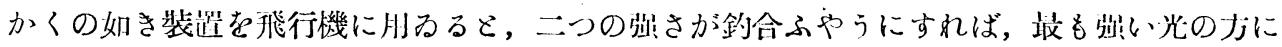

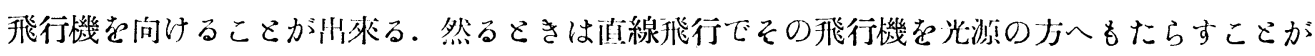
出來る。

\section{2. 上方或は下方から一樣に照らされた雲の層}

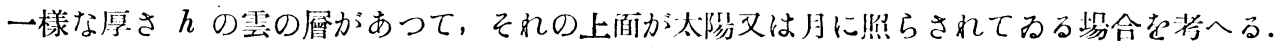

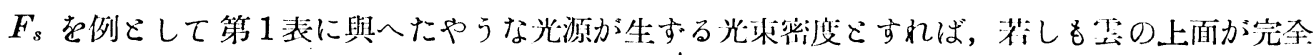
嚽散反射體であるならば，それの虺度は

$$
H_{s}=\left(F_{s} / \pi\right) \sin \alpha
$$

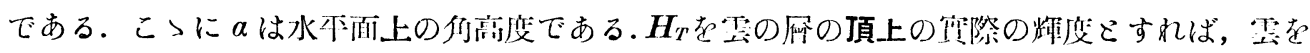

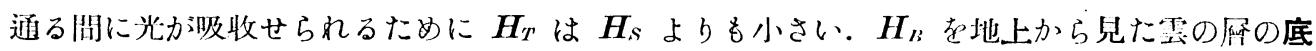

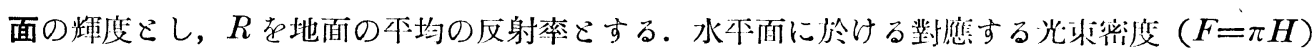
は $F_{T}$ 及び $F_{B}$ である. そして地面に澾する光州は $F_{B}$ で, 地面汃ら反るのは $R F_{n}$, 地面

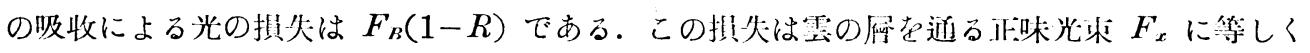
なければならなく，又雲の層の頂上に於ける正味の投射 $F_{s} \sin a-F_{T^{\prime}}$ に等しくなければなら ない.かくして式 (24) 及び（32）によつて

$$
H_{h}(1-R)=\frac{4 \lambda}{3 h}\left(H_{T}-H_{H}\right)
$$

及び

$$
H_{H}(1-R)=H_{S}-H_{T}
$$

二つの變数 $H_{T}$ 炎び $H_{n}$ 老分離して次の式老得る。

$$
\frac{3 h}{4 \lambda}=\frac{H_{T}}{H_{S}-H_{T}}-\frac{1}{1-R}
$$

及び

$$
\frac{3 h}{4 \lambda}=\frac{H_{S}-H_{B}}{H_{B}(1-R)}-1
$$

$H_{T}$ 及び $H_{B}$ の测定は飛行機から容易に行はれる。而して同時に $h$ を测れば色々の型の雲の 層に對する入の值を求めることが州來る。然しながら，地面からの测定だけでも有俆な次料を

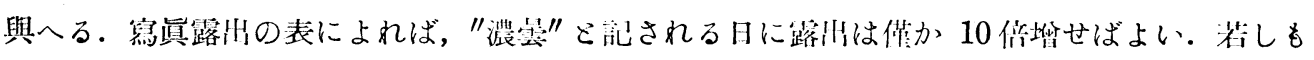
これ等の條件の下に於て，雲の層の上面が投射光の $90 \%$ 苍父射するならば，尝の首の中で吸

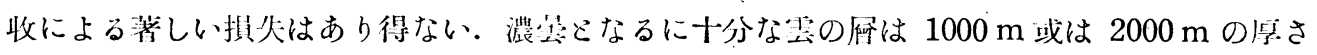
こ想像せられるが,これだけの屏は, 地面に於ける耀度寺 $H_{n}: H_{s}=1: 10$ の此に變化させ る. 式 (36) 加 


$$
\frac{3 h}{4 \lambda}=\frac{8+R}{1-h}
$$

空港の塔で行つた测定によれば，地面の反射率 $R$ は通常非常に小さい，例へば空港の地面の

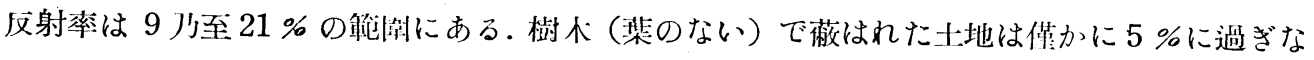
い. 前の式か嬹へる $h / \lambda$ の佔は $R$ に餘り影響せられないから， $R=0.1$ 及び $R=0.2$ に對し

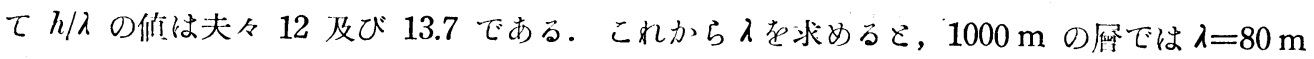
で, $2000 \mathrm{~m}$ の简では $\lambda=160 \mathrm{~m}$ である.

例へば規则正しく排列せられてるる燈火等で下から一㥞に㠫らされてるる雲の層に於ては, 問題は今述べたものとは異なり, 雲の虚の底面から下の方へ反射せられる光 $F_{B}$ は一部分地面

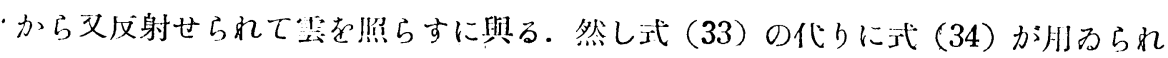

$$
H_{T}=\frac{4 \lambda}{3 h}\left(\dot{H}_{B}-H_{r}\right)
$$

又式（35）及び（36）の代らに

$$
1+\frac{3 h}{4 \lambda}=\frac{H_{s}-H_{T}}{H_{T}(1-R)}
$$

及び

$$
\frac{3 h}{4 \lambda}=\frac{H_{B}(2-R)-H_{S}}{H_{S}-H_{B}(1-R)}
$$

こっに $H_{S}$ は罢の底面が完全に反射し，且つ地面が完全に反射しないてきの底面の輝度であ る. 若しも $F_{S}$ が地面に於ける, 光源からの本均の鉛直光束密度であるならば $H_{S}=F_{S} / \pi$ て

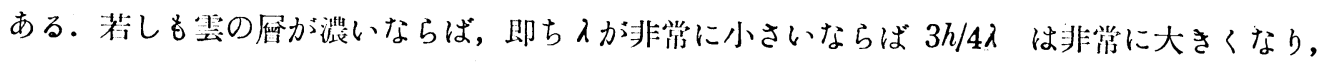
$H_{B}$ は

$$
H_{B}=H_{S} /(1-R)
$$

に近づき，かくして，淮しも地面の反射率が大きいならばHならも非常に大きくなることは 注意すべきである.（式 (36a)による).

\section{3. 反射率の小さい地面に近い霧の中の點光源}

地面がよい反射䯏である場合の例は饭に述べた，次に地面が完全に㫮く $(R=0)$, 光源が地面 上离さ $b$ の點 $B$ にある埸合を若へる.

地面は浽けるすべての光を吸收するから，蓩の外面に於けると全く同樣に地面に於て $H=0$ である、霧は無限た湠いと假定して閣題を簡單にすることが州來る，かくすれば，閒題は電釆

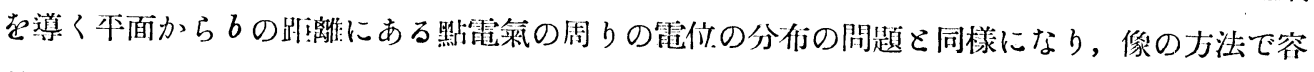

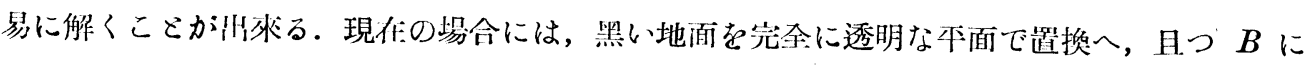

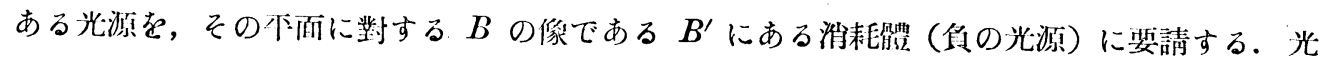




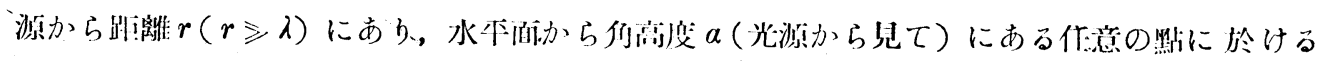
輝度 $\boldsymbol{H}$ は

$$
H=\frac{3 L_{u} b}{4 \pi^{2} \lambda r^{2}} \sin \alpha
$$

この式に於て， $L_{u}$ は光源が上方に即ち上牛球に發する光來 $(\mathrm{lm})$ 表はす，下才に發する 光は直ちに地面に吸收せられるからこの區帅は必罗である。重際の場合に，下方に向ふ光を少 效な上方に向ふ光に變へるために, 光源の下に牛球形の反射器を遗けば光源の效率は殆ど 2 倍 とすることが出來る.この昜合に $L_{u}$ は大略光源の總光束 $L$ に等しい。

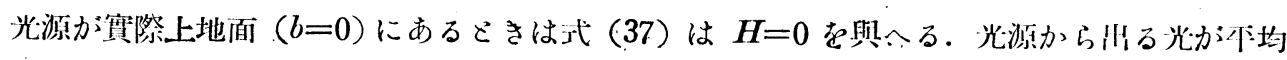

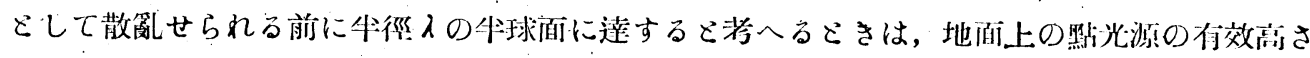
は大略 $2 \lambda / 3$ であることを知る。若しも光を鉛淔に上Jに集めるならば，それの有效高さ*は

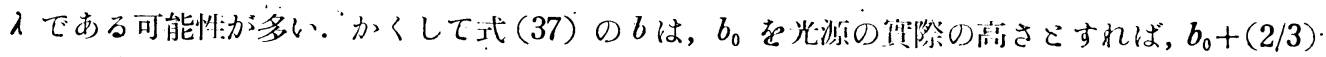

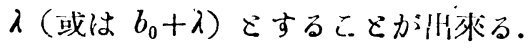

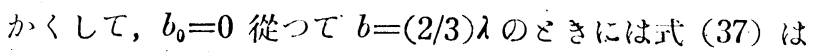

$$
H=L_{u} \sin a / 2 \pi^{2} r^{2} .
$$

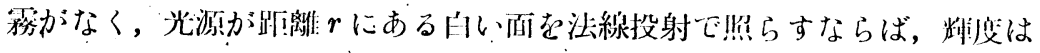

$$
H=L_{1} / 2 \pi^{2} r^{2}
$$

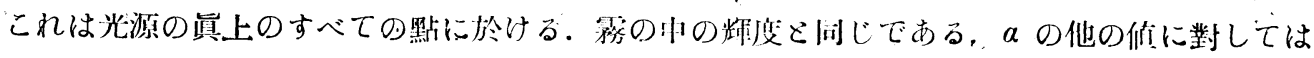
輝度は小さい.

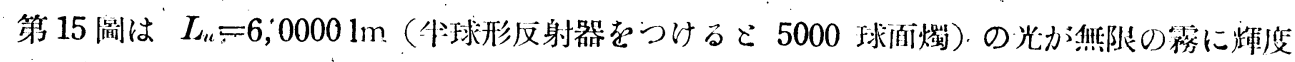

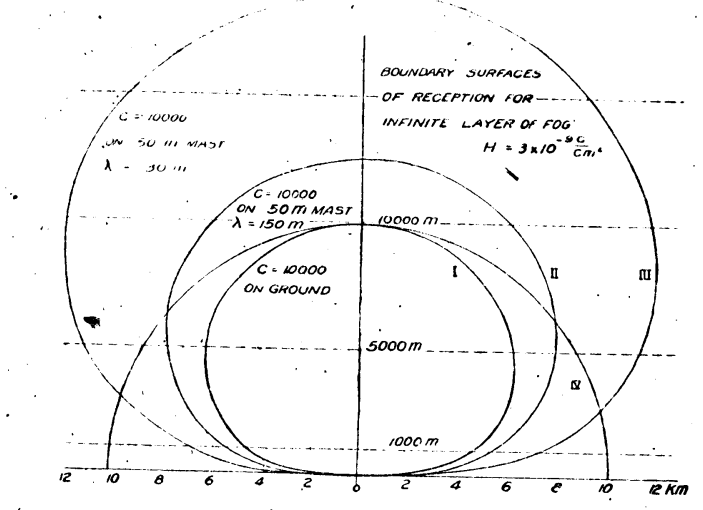

第 15 圖附近に上牛球に $6,0000 \mathrm{~lm}$ を投射する光源がある黑色地面

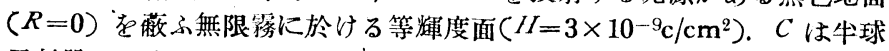
反射器附の光源の上方の光度である.

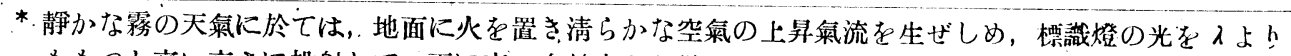
るつと高い高さに投射して，更に高い有效高さを得ることが出來る. 


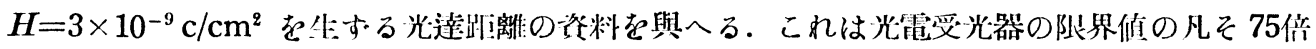
である。

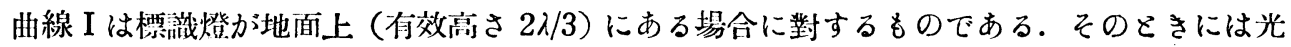

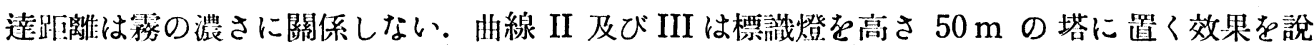
明する，光達距離は著しく增し，今や浱い霧に對して淺い霧よりも相嘗大きくなり，霧の浱さ

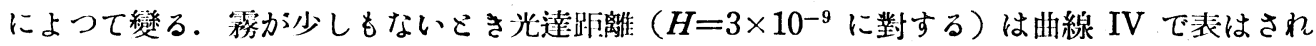
る.これは式 (38a) によつて曲線 I の最大の高さに等しい牛徑の牛圓である。曲線 III こ

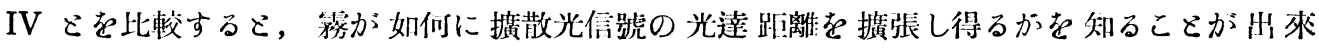
る.

$x$ 支光源からの水本距離こすれば $(x=r \cos a)$ 式（37）を部分微分し式（24）と組合はせ， 仕意の點に於ける正味光來密度の水本成分を求めると

$$
F_{x}=\frac{3 L_{u} b}{\pi r^{3}} \sin a \cos a
$$

月.式 (30) によつてJ向比は

$$
\underset{H}{\Delta H_{x}}=(4 \lambda / r) \cos \alpha
$$

これは光源の高さ $b$ に關係しない.

若しも受光器が仅對の力向の光の間の $1.5 \%$ の善を檢知することが出氷るならば,凡そ $200 \lambda$ 或は $10 \mathrm{~km}$ (若しも $\boldsymbol{H}$ が $3 \times 10^{-9}$ 佃大きいとき)の距離に於て方向效果を與へることが出來 3 .

\section{4. 霧又は需の一樣な層の中の點光源}

(a) 白い地面 $(R=1)$

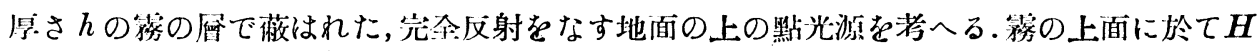
$=0$ である.像の方法によればこの䦌題は,相隣る電氣の距離旕 $2 h$ で鉛直線上に排列せられた 正及び貝の電篓の交无の排列が生する電仿分价の決定と同樣である. Madelung (8) びイオンで組立てられてるる結晶に於ける電氣力の研究に於ける同樣な問題を解いた。完全な 解は Hankel 豚數を使はないと表はすことが州來ないが，表が利用せられる。吾々は主とし て, 雲の屏の厚さ $h$ に比へて光源から可なり遠い距離に於ける輝度の分布に興味を有する。こ のときには式はすつと簡品になる，次の式は Madelung の式を輝度の分布の計算に適するや うに直したものである。

地面から高さ $y$ で, 標識燈から水本距離 $x$ である，䇰の層の內の任意の點に於て輝度 $H$ は

(8) E. Madelung, Phys Zeits. 19, 524-532 (1918). 


$$
H=\frac{3 L e^{-\pi x / 2 h} \cos (\pi y / 2 h)}{4 \pi^{2} \lambda h^{1 / 2} x^{1 / 2}} .
$$

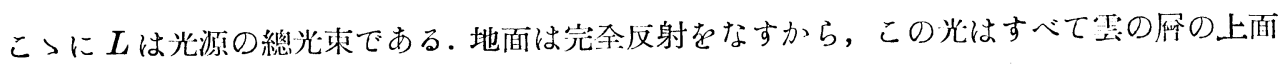
から逃げて行く。この式は $h$ に比べて大きい $x$ の值に對して正碓である. 然しながら， $h / 3$ 什

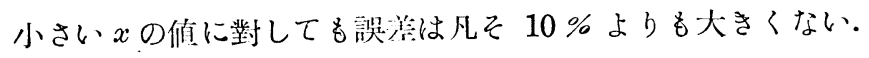

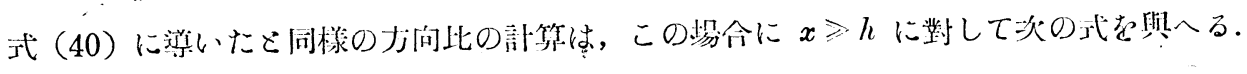

$$
\triangle H_{x} \doteq 2 \pi \lambda / 3 h
$$

標識燈の県上の點に於ける霧の上面の輝度 $H_{0}$ は, $x=0, y=h$ であつて（西確に）

$$
H_{0}=0.09280 L / h^{2} \text {. }
$$

$x>h$ である上面の點に於て, 輝度 $H_{0}$ は

$$
H_{0}=\frac{L e^{-\pi x / 2 h}}{2 \pi h^{3 / 2} x^{1 / 2}} .
$$

これ等の結果を呤味するこ，霧の中及び上面に於ける輝度は，水平距離力゙大るくなるこ指數 的に小さくなり，距離肪 $0.63 h$ 大きくなる符に $1 / e$ になるこてがわかる。

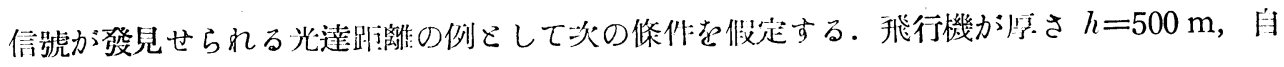
由行路 $\lambda=50 \mathrm{~m}$ の䨏の層の小, 高さ $y=250 \mathrm{~m}$ の所苍飛んでるる. 地面は等で蔽はれ, 地面

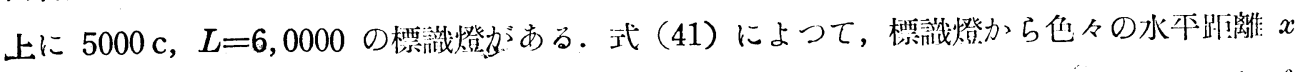
に於ける $\mathrm{c} / \mathrm{cm}^{2}$ で表はされた輝度を求めると，1，2，3，及び $4 \mathrm{~km}$ に於て夫々 $1.2 \times 10^{-6}$ ， $3.7 \times 10^{-8}, 1.3 \times 10^{-9}$, 及び $5 \times 10^{-11}$ である，かくして $4 \times 10^{-11} \mathrm{c} / \mathrm{cm}^{2}$ は發見し得るから， 信號は光源から 3 万与至 $4 \mathrm{~km}$ の距離に於て認められ得る. 凡そ $20 \%$ の才问比は $3 \mathrm{~km}$ 以下の 距離に於てょい方向效果を與へる。雲の層の頂上に於ける輝度 $H_{0}$ は $3 \lambda / h$ 即ち $200 \mathrm{~m}$ の离

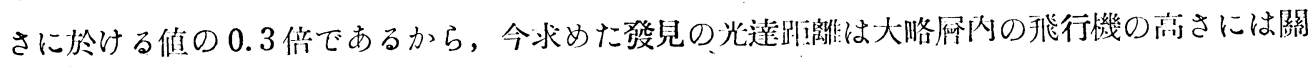
係しない.

\section{(b) 黑い地面 $(R=0)$}

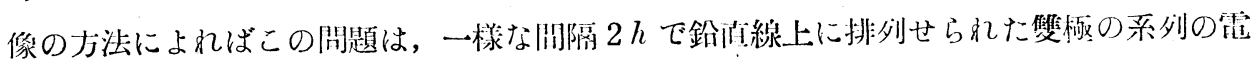

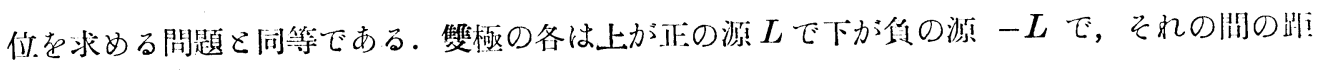
離が $2 b$ である.

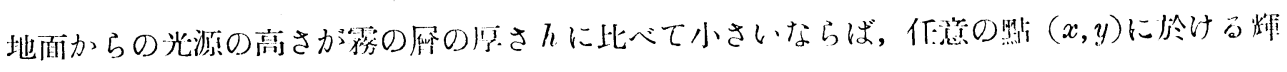
度 $H$ は

$$
H=\frac{3 L_{u} b}{2^{3 / 2} \pi \lambda h^{3 / 2} x^{1 / 2}} \sin \left(\begin{array}{c}
\pi y \\
h
\end{array}\right) e^{-(\pi x / h)}
$$

Luは前の如く满識燈が上方に發する總べての光来である。 


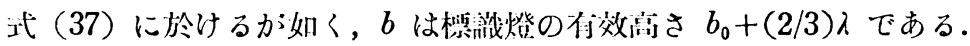

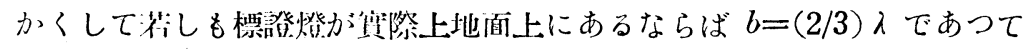

$$
H=\frac{L_{u} \sin (\pi y / h) e^{-\pi x / h}}{2^{1 / 2} \pi h^{3 / 2} x^{1 / 2}} .
$$

$x \geqslant h$ に對してJ向比を郭算するこ

$$
\frac{\triangle H_{x}}{\boldsymbol{H}}=4 \pi \lambda / 3 h
$$

これは $R=0$ に對する式 (42)か與くる值の 2 倍である.

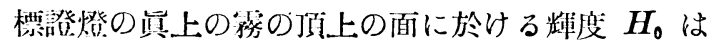

$$
H_{0}=0.4262 b L_{u} / h^{3} \text {. }
$$

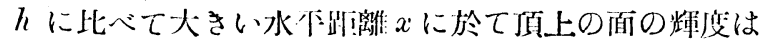

$$
H_{0}=\frac{2^{3 / 2} L_{n} \lambda e^{-\pi x / h}}{3 h^{5 / 2} x^{1 / 2}} .
$$

蓩の上面からの，總光柬 $L_{0}(\mathrm{~lm})$ の近似積分は

$$
L_{0}=2 L_{u} b / h \text {. }
$$

$x$ が大きくなるごきの輝度の對數減望は，地面が白い埸合の 2 倍であることは注意すべきで ある。

例として前の如く $5000 \mathrm{c}\left(L_{u}=6,0000\right)$ の標詠燈を採る. $h$ 及び $x$ の色々の值に對して, 式 （46）によつて 標證燈が地面に近い場合に對して高さ $y=0.5 \dot{h} に$ 於ける $H$ を計算した．第 VIII 表は， $H$ が第 I 欄に指示せられた值を有する距離を與へる. $4 \times 10^{-11} \mathrm{c} / \mathrm{cm}^{2}$ を檢知し 得る光電受光器では 1 乃至 $3 \mathrm{~km}$ の光達距離が可能である. 0.5 以外の高さに於ては結果は 餘り異ならない.

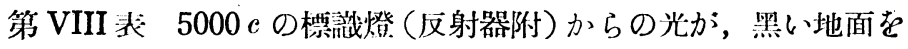
蔽ふ厚さ $h$ の落の屏の內部に於て與へられた輝度を生する距離:

\begin{tabular}{c|c|c|c}
\hline \multirow{H}{*}{$\begin{array}{c}\mid c \\
\left(\mathrm{c} / \mathrm{cm}^{2}\right)\end{array}$} & 250 & 500 & 1000 \\
\hline $10^{-8}$ & 580 & 950 & 1500 \\
$10^{-9}$ & 760 & 1300 & 2180 \\
$10^{-10}$ & 930 & 1640 & 2870 \\
$4 \times 10^{-11}$ & 1000 & 1780 & 3140
\end{tabular}

標識燈の光来が 10 侮になるか, 㖪は有效高さ $b$ が10借になつても, 標識燈からの光が光雷 


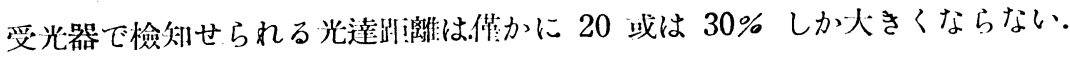

これ等の资料を完全反射の地面に對して部算したものと比较して，地面を然くすることの影 響は，完全反射の地面に對する光達跳離の值を凡そ $42 \%$ 小さくするこてであるここを知る。

\section{5. 雲の層からの反射とこれを通しての透過}

上に述べ地面に接してるる霧の薄い層は，霧の首の內部を光が通ることに對しては，恐ら

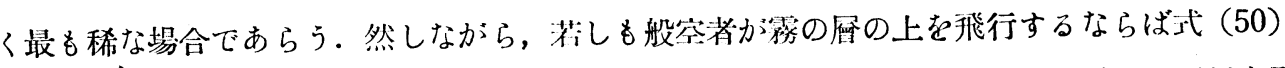

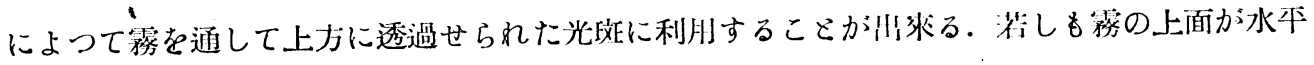

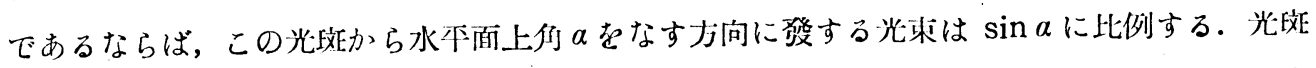
から距離 $\boldsymbol{r}($ 傾いた線に沿うて)，霧の首の頂上の上高さ $y$ に於ける仕意の點に於ける光来密度 $F$ は

$$
F=L_{0} y / \pi r^{3}=2 L_{u} b y / \pi h r^{3} .
$$

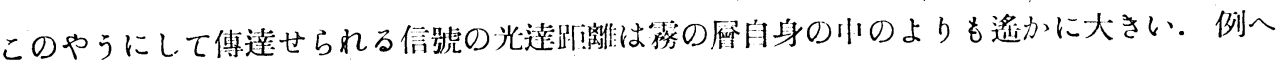
ば, $\boldsymbol{L}_{u}=6,0000, b=(2 / 3) \lambda, \lambda=50 \mathrm{~m}, h=250 \mathrm{~m}$ と置いて $F=5100 \mathrm{y} / \mathrm{r}^{3}$ を得る。蒲しも $y=2.5$ $\times 10^{4}(250 \mathrm{~m})$ 及び光電受光器の限界輝度 $\left(H=4 \times 10^{-11}\right)$ に對應して $F=1.2 \times 10^{-10}$ と取れ

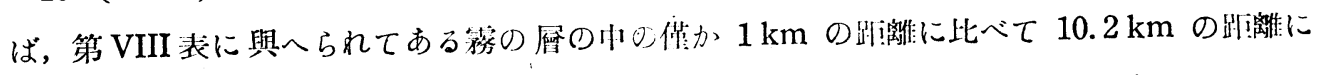
於ける霧を透して傅達せられた變調せられた光を檢知するここが忺來るここがわかる。

地面にある霧の上方に更に雲戦層にも重なつてるるならばこれ等から下に反射せられる

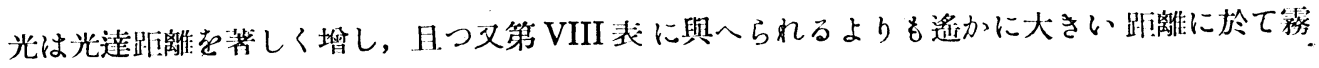
の層の中の光を發見することを得しめる。

若しも蓩の瓷の底面が地面から高さ $y_{0} に$ にるならば，標識燈からの光は $L_{u}$ 琴の底面に光

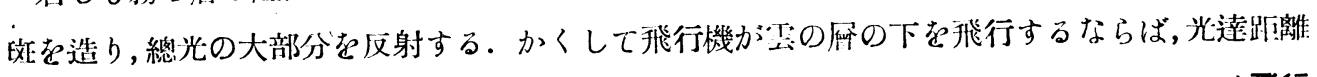
は式（51）の最初の 2 項で計算することが出來る.こつに $L_{0}$ は $L_{u}$ で澹换へられ，yは飛行 機の上の天井の高さである。

雲の層が地面から著しく離れてるるときには，それを通しこの光の透過は式(35a)及び(36a)

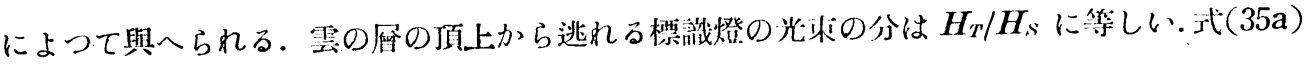
によつて

$$
H_{T} / H_{S}=1 /[1+(1-R)(1+3 h / 4 \lambda)] \text {. }
$$

$R=0$ で $h / \lambda$ が大きいときにはこれは黑い地面に横はる陊の堔合に對する式 (50) で與へら れる比 $L_{0} / L_{u}$ そ同じ值となる.かくして式 (51) はなほ，地面上可なりの京さにある零の層を 通して透過する光の發見に對して適用し得る。

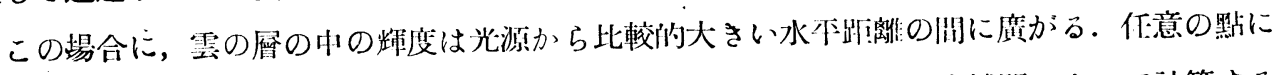
於ける輝度 $H$ は式 $(35 \mathrm{a})$ 及び $(36 \mathrm{a})$ が與へる $H_{B}$ と $H_{T}$ この間の一次䘞间によつて計算する 


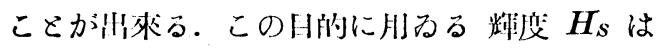

$$
H_{S}=L_{u} y_{0} / 2 \pi^{2} r^{3}
$$

に等しい。こつに $r$ は光源から等の底面にある與へられた點までの傾いた距離である. $r \geqslant y$

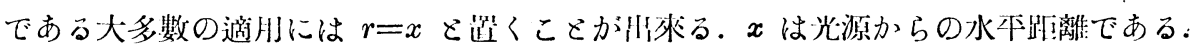

これ等の條作の下に於て式（53）の部分微分と式 (24) 及び（30）との組合はせによつて才 向比は

$$
\frac{\Delta H_{x}}{H}=-\frac{4 \lambda}{x}
$$

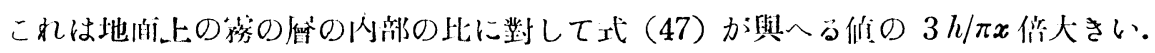

一例として，底面が文射率 $R=0.2$ の地面の上 $y_{0}=500 \mathrm{~m}$ にある厚さ $h=500 \mathrm{~m}$ の筀の应を 考へる. $\lambda=50 \mathrm{~m}$ 及び $L_{u}=6,0000 \mathrm{~lm}$ をする. 式 (53) にようて. $H_{S}=1.5 \times 10^{8} / \mathrm{r}^{3} \mathrm{c} / \mathrm{cm}^{2}$ を 得, それか. ら式 (35a) 及び (36a) によつて $H_{T^{\prime}}=1.3 \times 10^{7} / r^{3}$ 及ひび $H_{B}=1.09 H_{S}=1.65 \times 10^{8} / r^{3}$

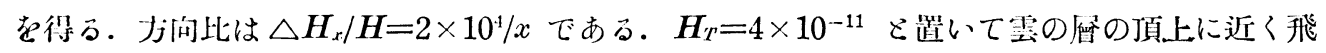

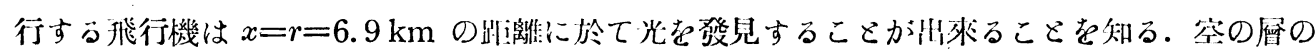
底面に近い所で光達距離は $1.61 \mathrm{~km}$ である. 1.65 及び $3.8 \mathrm{~km}$ (頂上及び底面) の距離に於

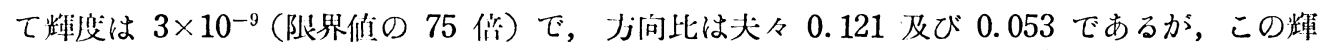
该では 0.015 老観测する。

\section{霧の中に於ける光の眞の吸收の影響}

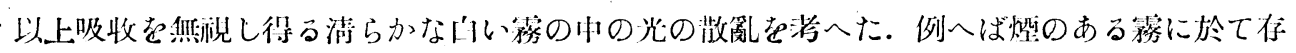
在する如さ光の吸收があるときに起る修正劣簡品に述べる。

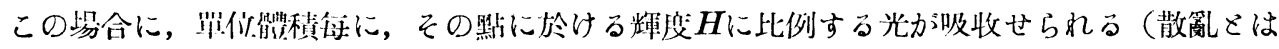
晎なつて消減する). 吸收は "體穔吸收係數" (Volume-absorption coefficient) A で测ること

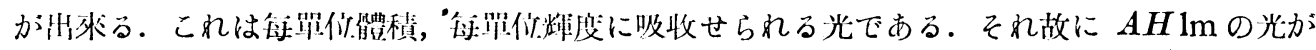
單位體積繁に吸收せられる。

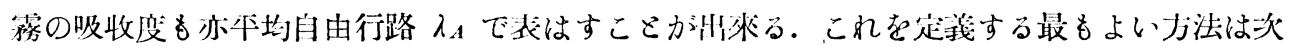
の關係を为放こことである。

$$
-\frac{d F}{F^{\prime}}=\frac{d x}{\lambda_{A}}
$$

こっにー- $d F$ は $d x$ だけ進む阙の吸收のための光來密度 $\boldsymbol{F}$ の減少である. 次の式が潑明せられる。

$$
\lambda_{A}=4 \pi / A
$$


こっで $H$ が唯一つの變數によつて變る特別な場合を考へる. 即ち $H$ が (1) 一定の平面

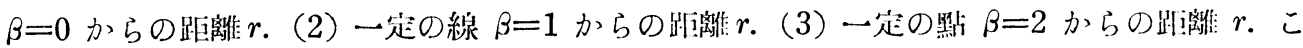

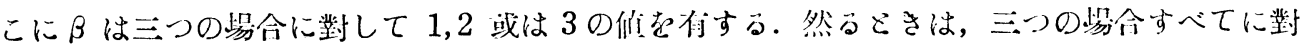

して Poisson の力程式によつて

$$
\frac{d^{2} H}{d r^{2}}+\frac{\beta}{r} \frac{d H}{d r}=\frac{3 H}{\lambda_{A} \lambda_{s}}
$$

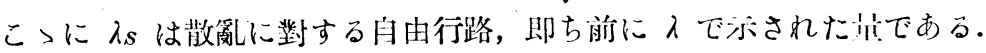

若しも $r=\infty$ に於て $H=0$ といふ境界條俳寺入れて式 (57) 教䅡分すと

\section{1. 平面の場合, $\beta=0$}

$$
H=H_{0} e^{-\left(3 / \lambda_{A} \lambda_{S}\right)^{1 / 2} r}
$$

こつに $H_{0}$ は一定の本面， $r=0$ に於ける輝度である. 微分してx（24）に遥换へると $r=0$ に 於ける光束密度 $F_{0}$ は

$$
F_{0}=4 \pi\left(\lambda_{s} / 3 \lambda_{A}\right)^{1 / 2} H_{0}
$$

\section{2. 圓壔の場合, $\beta=1$}

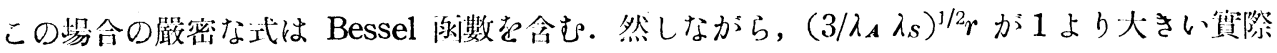
の晹合には，头の式は十分な近似值老與へる。

$$
H=0.03618 \lambda_{A} A^{1 / 4} \lambda_{S}{ }^{-3 / 4} r^{-1 / 2} L_{1} e^{-\left(3 / \lambda_{A} \lambda_{S}\right)^{1 / 2} r}
$$

こつに $L_{1}$ は單储主さ每の，ルーメンで表はした線光源の光柬である。

3. 球の場合, $\beta=2$

$$
H=\left(3 L / 16 \pi^{2} \lambda_{s} r\right) e^{-\left(3 / \lambda_{A} \lambda_{s}\right)^{1 / 2} r}
$$

こっに $L$ はルーメンで表はした點光渲の光束である。

吸收がないと式（26）は

$$
H=3 L / 16 \pi^{2} \lambda_{s} r .
$$

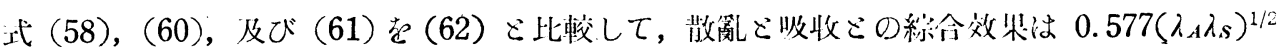
に等しい有效自由行路 老與へること支知る。これ等の式には指数因数があるから，们罗な信

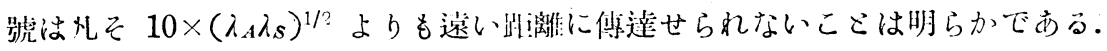

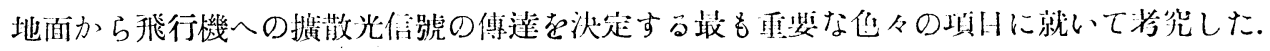

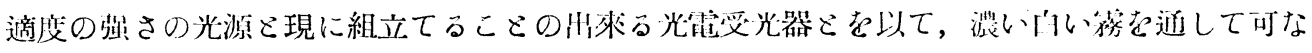

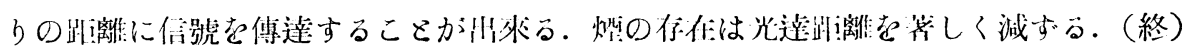

